\title{
Analysis of genetic variability of penicillinase non-producing Neisseria gonorrhoeae strains with different levels of resistance to penicillin
}

\author{
L. DE LA FUENTE and J. A. VÁZOUEZ
}

Servicio de Bacteriología, Centro Nacional de Microbiología, Instituto de Salud Carlos III. 28220 Majadahonda (Madrid), Spain

\begin{abstract}
Summary. Genetic variability among 41 penicillinase non-producing Neisseria gonorrhoeae strains, isolated in Spain, with different levels of resistance to penicillin was investigated by multilocus enzyme electrophoresis. Based on the results obtained by analysis at seven enzyme loci, the strains were separated into 17 electrophoretic types. The average number of alleles/enzyme locus was 2.85 ; the mean genetic diversity/locus was 0.49 for individual isolates and 0.516 for electrophoretic types. The results showed that these gonococcal strains were, genetically, a highly variable group of organisms.
\end{abstract}

\section{Introduction}

Strains of Neisseria gonorrhoeae with chromosomal resistance to penicillin (MIC $\geqslant 1 \mathrm{mg} / \mathrm{L}$ ) have been reported worldwide. ${ }^{1-3}$ In Spain, on average, such strains comprise about $5 \%$ of isolates. ${ }^{4}$ Chromosomal resistance to penicillin in $N$. gonorrhoeae results from the additive effects of mutations at several distinct loci. ${ }^{5}$ These different mutations also increase resistance to hydrophobic antibiotics and tetracycline. ${ }^{6}$

The purpose of this paper was to determine the genetic variability in penicillinase non-producing strains of $N$. gonorrhoeae (Non-PPNG) resistant to penicillin. Multilocus enzyme electrophoresis was used to study 41 Non-PPNG strains, belonging to various auxotype:serovar classes, and exhibiting different levels of resistance to penicillin. The strains examined were isolated in Spain during 1989.

\section{Materials and methods}

\section{Bacterial strains}

The 41 Non-PPNG strains investigated are listed in table I. The strains belonged to 31 different auxotype:serovar classes (table I); methods for gonococcal auxotyping and serovar determination were described previously. ${ }^{78}$ Antibiotic susceptibility tests were performed by an agar dilution technique. ${ }^{7}$ The range of MICs to penicillin is shown in table I.

\section{Preparation of enzyme extracts}

Strains were grown overnight on GC Agar (Difco)

Received 16 Sept. 1991; accepted 4 Nov. 1991 containing Kellogg's supplement $1 \%^{9}$ at $37^{\circ} \mathrm{C}$ in $\mathrm{CO}_{2}$ $5 \%$. The bacterial cells were harvested into $2 \mathrm{ml}$ of $10 \mathrm{~mm}$ Tris $(\mathrm{pH} 8.0)$, vigorously resuspended with a mechanical mixer, and frozen at $-20^{\circ} \mathrm{C}$ for at least $18 \mathrm{~h}$. After thawing, the preparations were centrifuged at $4000 \mathrm{~g}$ for $30 \mathrm{~min}$; the cleared lysate, containing enzymes released by freezing and thawing, was removed and stored at $-70^{\circ} \mathrm{C}$.

\section{Isoenzyme electrophoresis}

Polyacrylamide gel electrophoresis was performed on vertical gel slabs with a discontinous buffer system. A separation gel, $8 \%$, was used with a stacking gel, $5 \%$, for all enzymes studied. The gel buffers were $0.375 \mathrm{~m}$ Tris, $\mathrm{pH} 8.8$, in the separation gel, and $0.125 \mathrm{~m}$ Tris, pH 6.8, in the stacking gel; the electrode buffer was $0.025 \mathrm{M}$ Tris and $0.19 \mathrm{M}$ glycine, $\mathrm{pH} 8.3$, with bromophenol blue as the tracking dye. Electrophoresis was at a constant current of $80 \mathrm{~V}$ at $4^{\circ} \mathrm{C}$ until the tracking dye reached the bottom of the gel. After electrophoresis the gel slabs were stained to visualise the enzymes.

\section{Enzyme staining procedure}

The activity of seven enzymes, listed in table II, was examined. Our objective was to distinguish strains for epidemiological tracing. For this purpose, the analysis of a few loci may be sufficient. Specific staining procedures for the enzymes were described previously. ${ }^{10}$ The relative mobilities of the enzyme bands were expressed in terms of the ratio of the distance that the enzyme had moved from the origin to the distance moved by the tracking dye. Chemicals used in staining the gels were obtained from Sigma. 
Table I. Characteristics of the 41 isolates of $N$. gonorrhoeae

\begin{tabular}{|c|c|c|c|}
\hline ET & $\begin{array}{l}\text { Number of } \\
\text { isolates }\end{array}$ & Auxotype:serovar & $\begin{array}{l}\mathrm{MIC}(\mathrm{mg} / \mathrm{L}) \\
\text { of penicillin }\end{array}$ \\
\hline 1 & 3 & Pro $^{-}:$Bopyuvt & 1 \\
\hline 2 & $\begin{array}{l}1 \\
1 \\
1\end{array}$ & $\begin{array}{l}\text { Zero:Arst } \\
\text { Zero:Bropyt } \\
\text { Pro }^{-}: \text {Bopyuvt }\end{array}$ & $\begin{array}{l}0.25 \\
0.5 \\
0.5\end{array}$ \\
\hline 3 & $\begin{array}{l}1 \\
1 \\
1 \\
1 \\
1 \\
1 \\
1\end{array}$ & $\begin{array}{l}\text { Pro- }^{-} \text {Bpyust } \\
\text { Zero:Bropyust } \\
\text { Pro-:Arst } \\
\text { Zero:Brpyust } \\
\text { Zero:Bopyuvt } \\
\text { Zero:Bropyt } \\
\text { Zero:Bopt }\end{array}$ & $\begin{array}{l}0 \cdot 25 \\
0 \cdot 5 \\
0 \cdot 25 \\
0 \cdot 25 \\
0 \cdot 25 \\
0 \cdot 25 \\
1\end{array}$ \\
\hline 4 & 1 & Zero:Aot & $0 \cdot 25$ \\
\hline 5 & $\begin{array}{l}1 \\
1 \\
1 \\
1 \\
1\end{array}$ & $\begin{array}{l}\text { Pro }^{-}, \text {Arg }^{-}: \text {Bropt } \\
\text { Pro } \\
\text {,Arg- }: \text { Bropt } \\
\text { Zero:Bopyust } \\
\text { Zero: Bopyt } \\
\text { Zero:Boys }\end{array}$ & $\begin{array}{l}4 \\
1 \\
1 \\
1 \\
2\end{array}$ \\
\hline 6 & 1 & Zero:Arst & 1 \\
\hline 7 & 3 & Zero:Bpyuvt & 1 \\
\hline 8 & 1 & Zero:Bopvt & 1 \\
\hline 9 & $\begin{array}{l}1 \\
1\end{array}$ & $\begin{array}{l}\operatorname{Pro}^{-}: \text {Arst } \\
\text { Arg }^{-}: \text {Avt }\end{array}$ & $\begin{array}{l}0.25 \\
0.25\end{array}$ \\
\hline 10 & $\begin{array}{l}1 \\
1 \\
1 \\
1\end{array}$ & $\begin{array}{l}\text { Zero: Byuvt } \\
\text { Zero:Aros } \\
\text { Zero: Brpyst } \\
\text { Pro- }^{-} \text {Bpyuvt }\end{array}$ & $\begin{array}{l}0 \cdot 25 \\
0.5 \\
0 \cdot 25 \\
0.5\end{array}$ \\
\hline 11 & $\begin{array}{l}1 \\
1\end{array}$ & $\begin{array}{l}\text { Met }^{-}: \text {Bropt } \\
\text { Pro }^{-}, \text {Arg }^{-}: \text {Brpt }\end{array}$ & $\begin{array}{l}0.25 \\
0.5\end{array}$ \\
\hline 12 & $\begin{array}{l}1 \\
1 \\
1\end{array}$ & $\begin{array}{l}\text { Pro }^{-}, \mathrm{Arg}^{-}: \text {Boyst } \\
\text { Zero: Bpyst } \\
\text { Hyx } \\
\text { Heyt }\end{array}$ & $\begin{array}{l}0 \cdot 25 \\
0 \cdot 5 \\
0 \cdot 5\end{array}$ \\
\hline 13 & $\begin{array}{l}1 \\
1\end{array}$ & $\begin{array}{l}\text { Zero: Bopst } \\
\text { Zero:Bropyut }\end{array}$ & $\begin{array}{l}0.25 \\
0.5\end{array}$ \\
\hline 14 & 1 & Zero:Bpyuvt & 0.5 \\
\hline 15 & 1 & Pro $^{-}:$Bpyvt & 0.5 \\
\hline 16 & 1 & $\mathrm{Arg}^{-}: \mathrm{Bx}$ & 0.5 \\
\hline 17 & 1 & Pro $^{-}:$Bropt & 2 \\
\hline
\end{tabular}

ET = electrophoretic type (see text).

\section{Statistical methods}

Each isolate was characterised by the combination of electromorphs obtained from the enzymes assayed; distinctive electromorph profiles were designated electrophoretic types (ETs).

The diversity at a genetic locus was calculated as: $\mathrm{h}=\left(1-\Sigma \mathrm{x}_{i}{ }_{i}\right)(\mathrm{n} / \mathrm{n}-1)$, where $\mathrm{x}_{i}$ is the frequency of the $i$ th allele, $\mathrm{n}$ is the number of ETs or isolates, and $\mathrm{n} / \mathrm{n}-1$ is a correction for bias in small samples. ${ }^{11}$ Mean genetic diversity $(\mathrm{H})$ is the arithmetic average of $h$ values over all loci.

Genetic distance (D) between pairs of isolates was calculated as the proportion of loci at which dissimilar alleles occurred, ${ }^{10}$ and clustering of ETs was performed from a matrix of genetic distances.

\section{Results}

Among the 41 isolates examined there were 17
Table II. Profiles of alleles at seven polymorphic enzyme gene loci in 17 ETs of $N$. gonorrhoeae

\begin{tabular}{|c|c|c|c|c|c|c|c|c|}
\hline \multirow{2}{*}{$\mathrm{ET}$} & \multirow{2}{*}{$\begin{array}{l}\text { Number of } \\
\text { isolates }\end{array}$} & \multicolumn{7}{|c|}{$\begin{array}{l}\text { Alleles at indicated polymorphic } \\
\text { enzyme gene locus }\end{array}$} \\
\hline & & $\mathrm{ME}$ & ALP & GOT & $\mathrm{GD} 2$ & G6P & IDH & LAP \\
\hline 1 & 3 & 2 & 3 & 1 & 2 & 1 & 2 & 2 \\
\hline 2 & 3 & 2 & 3 & 1 & 1 & 1 & 3 & 2 \\
\hline 3 & 7 & 2 & 3 & 1 & 1 & 1 & 4 & 2 \\
\hline 4 & 1 & 2 & 3 & I & 2 & 1 & 3 & 2 \\
\hline 5 & 5 & 2 & 1 & 1 & 1 & 1 & 2 & 2 \\
\hline 6 & 1 & 2 & 1 & 1 & 1 & 1 & 3 & 2 \\
\hline 7 & 3 & 2 & 1 & 2 & 2 & 1 & 2 & 2 \\
\hline 8 & 1 & 2 & 3 & 2 & 1 & 1 & 2 & 2 \\
\hline 9 & 2 & 1 & 1 & 2 & 1 & 1 & 4 & 2 \\
\hline 10 & 4 & 1 & 1 & 3 & 1 & 2 & 4 & 2 \\
\hline 11 & 2 & 1 & 2 & 3 & 1 & 1 & 4 & 2 \\
\hline 12 & 3 & 1 & 2 & 1 & 1 & 2 & 4 & 2 \\
\hline 13 & 2 & 1 & 2 & 1 & 1 & 1 & 2 & 2 \\
\hline 14 & 1 & 1 & 2 & 3 & 2 & 2 & 2 & 2 \\
\hline 15 & 1 & 2 & 1 & 3 & 1 & 1 & 1 & 2 \\
\hline 16 & 1 & 1 & 4 & 1 & 1 & 1 & 2 & 1 \\
\hline 17 & 1 & 1 & 1 & 2 & 1 & 1 & 5 & 2 \\
\hline
\end{tabular}

ME, malic enzyme; ALP, alkaline phosphatase; GOT, glutamicoxalacetic transaminase; GD2, glutamate dehydrogenase (NADP); G6P, glucose 6-phosphate dehydrogenase; IDH, isocitrate dehydrogenase; LAP, leucine aminopeptidase.

Table III. Frequencies of alleles at seven enzyme loci in ETs of $N$. gonorrhoeae

\begin{tabular}{lcc}
\hline Locus & Allele & Frequency of alleles $(\mathrm{n}=17)$ \\
\hline ME & 1 & $0 \cdot 47$ \\
& 2 & $0 \cdot 52$ \\
ALP & 1 & $0 \cdot 41$ \\
& 2 & $0 \cdot 23$ \\
& 3 & $0 \cdot 29$ \\
GOT & 4 & $0 \cdot 05$ \\
& 1 & $0 \cdot 52$ \\
& 2 & $0 \cdot 23$ \\
GD2 & 3 & $0 \cdot 23$ \\
& 1 & $0 \cdot 76$ \\
G6P & 2 & $0 \cdot 23$ \\
& 1 & $0 \cdot 76$ \\
IDH & 2 & $0 \cdot 23$ \\
& 1 & $0 \cdot 05$ \\
& 2 & $0 \cdot 41$ \\
& 3 & $0 \cdot 17$ \\
& 4 & $0 \cdot 29$ \\
LAP & 5 & $0 \cdot 05$ \\
& 1 & $0 \cdot 05$ \\
& 2 & $0 \cdot 94$ \\
& &
\end{tabular}

Abbreviations are as in table II.

distinct multilocus genotypes or ETs (table II). All seven enzymes assayed were polymorphic. Allele frequencies in this group of ETs are presented in table III. The average number of alleles/locus was $2 \cdot 85$. The mean genetic diversity/locus $(\mathrm{H})$ was 0.49 for individual isolates and 0.51 for ETs (table IV). The 
Table IV. Genetic diversity of $N$. gonorrhoeae strains

\begin{tabular}{lclc}
\hline & $\begin{array}{c}\text { Number of } \\
\text { Llleles* }\end{array}$ & \multicolumn{2}{c}{ Genetic diversity } \\
\cline { 3 - 4 } & & ETs $\dagger$ & Isolates $\ddagger$ \\
\hline ME & 2 & 0.54 & 0.52 \\
ALP & 4 & 0.742 & 0.717 \\
GOT & 3 & 0.66 & 0.64 \\
GD2 & 2 & 0.39 & 0.38 \\
G6P & 2 & 0.39 & 0.38 \\
IDH & 5 & 0.77 & 0.74 \\
LAP & 2 & 0.12 & 0.12 \\
\hline
\end{tabular}

Abbreviations are as in table II.

* Mean number of alleles $=2 \cdot 85$.

$\dagger$ Mean diversity/locus for seven enzyme loci $=0.516$.

$\ddagger$ Mean diversity/locus for seven enzyme loci $=0.499$.
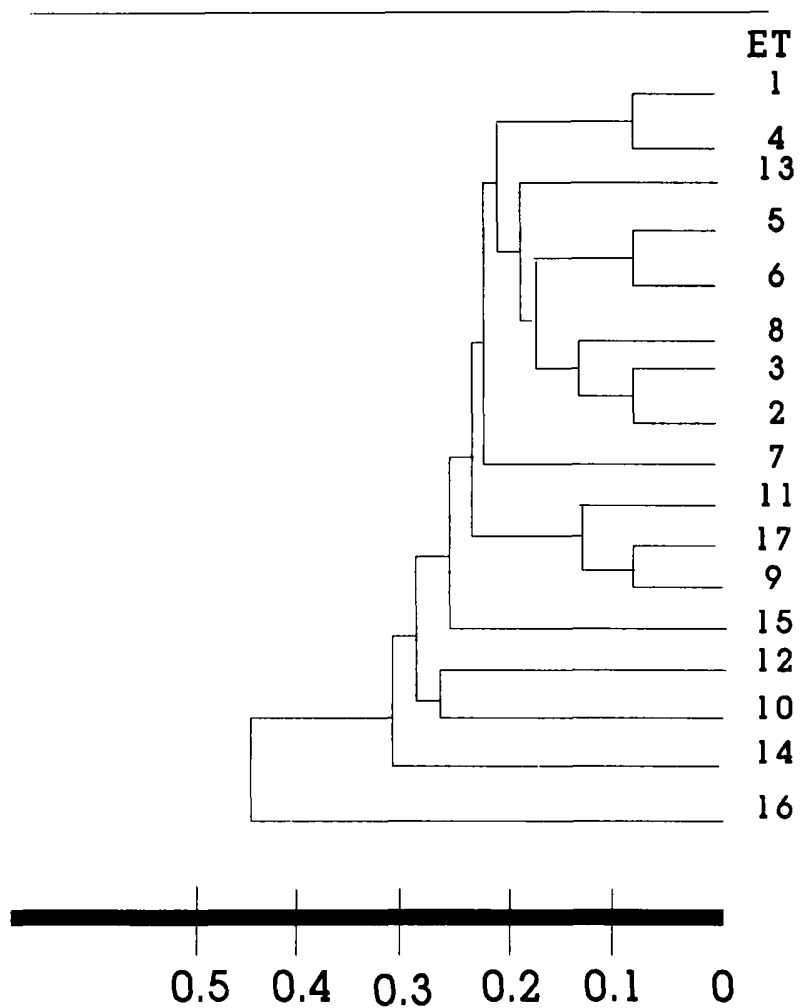

Figure. Genetic relationships among the 17 electrophoretic types (ETs).

relationships among the 17 ETs are shown in the figure. The smallest genetic distance $(0.09)$ observed between ETs in the dendrogram corresponds with a single locus difference, and the largest distance $(0 \cdot 45)$ corresponds with differences at five of the seven loci assayed.

Clustering of the 17 ETs revealed six divisions at a genetic distance of $0 \cdot 28$, each represented by a cluster of ETs or, in some cases, by a single ET. Of the ETs, $70.5 \%$ (represented by $72.7 \%$ of the isolates) belonged to two large clusters (A and B) composed of (A): ETs $1,2,3,4,5,6,7,8$ and 13; (B): ETs 11,17 and 9, at a genetic distance of $0 \cdot 23$. Clusters $\mathrm{C}, \mathrm{E}$ and $\mathrm{F}$ each contained single ETs $(15,14$ and 16 , respectively) represented by one isolate. Cluster $\mathrm{D}$, at a genetic distance of 2.7, contained ETs 10 and 12 .

The ET designations of the strains were not absolutely linked to any particular auxotype: serovar class (table I).

\section{Discussion}

$N$. gonorrhoeae exhibits high levels of chromosomal resistance to various antimicrobial agents ${ }^{12}$ and, since its introduction, gonococcal isolates have become increasingly less susceptible to penicillin. ${ }^{13}$ It is difficult to determine whether penicillin resistance has a clonal origin, but it is possible to examine whether chromosomal resistance to penicillin occurs in many different strains or only in a homogeneous group. In this paper, we have performed multilocus enzyme analysis to determine the genetic variability among 41 gonococcal strains exhibiting different levels of resistance to penicillin. A similar study has been performed with $N$. meningitidis strains showing increased levels of resistance to penicillin, ${ }^{14}$ and the method has proved to be useful for studies of this type.

The results show that $N$. gonorrhoeae strains are, genetically, a highly variable group of organisms. A minimum of 17 ETs (genotypes) were found among the 41 strains examined, with an average of 2.85 alleles/enzyme locus and a mean genetic diversity/ locus of $c .0 \cdot 5$. These data indicate that genetic variation in gonococcal strains is comparable to that found in N. meningitidis, Haemophilus spp. and Escherichia coli. ${ }^{14-16}$

Different levels of penicillin resistance among the gonococcal isolates examined (table I) were not related to clustering among the isolates; thus strains with three different MICs grouped in ET3 or in ET5. This finding could mean that strains in a genetically homogeneous group can acquire different levels of resistance to penicillin. However, of 15 strains with an MIC of $\geqslant 1 \mathrm{mg} / \mathrm{L}, 14$ belonged to cluster A (table I and figure), thereby suggesting a clonal origin for strains of this type. Analysis of a larger number of strains resistant to penicillin, with diversity in their geographical origin and date of isolation, might confirm this finding.

In contrast, the distribution of strains between the ETs was not linked to any particular auxotype:serovar class (table I). The variability by auxotype:serovar class was larger than that found in the multilocus enzyme analysis. Some ETs were formed of strains in different auxotype:serovar classes (ET3 and ET5), whereas others were formed of isolates belonging to the same auxotype:serovar class (ET1 and ET7). Classification of the strains by auxotype:serovar did not seem to be related to their genotypes.

The authors thank J.M. Arredondo for help with the data analysis and $\mathrm{C}$. M. Bourgon for suggestions during the preparation of the manuscript. 


\section{References}

1. Dowsett EG. Penicillin-resistant gonococci. Lancet 1980; 2: 202 (letter).

2. Rice RJ, Biddle JW, JeanLouis YA, DeWitt WE, Blount JH, Morse SA. Chromosomally-mediated resistance in Neisseria gonorrhoeae in the United States: results of surveillance and reporting, 1983-4. J Infect Dis 1986; 153: $340-345$.

3. Van Klingeren B, Ansink-Schipper MC, Doornbos L et al. Surveillance of the antibiotic susceptibility of non-penicillinase producing Neisseria gonorrhoeae in the Netherlands from 1983 to 1986. J Antimicrob Chemother 1988; 21 : 737-744.

4. Nogueira JM, Palomares JC, Vázquez JA. Epidemiología del gonococo en España. Rev Iberoam Enf Trans Sex 1990; 4: 9-15.

5. Maier TW, Zubrzycki L, Coyle MB, Chila M, Warner P. Genetic analysis of drug resistance in Neisseria gonorrhoeae; production of increased resistance by the combination of two antibiotic resistance loci. J Bacteriol 1975; 124: 834-842.

6. Sparling PF. Genetic transformation of Neisseria gonorrhoeae to streptomycin resistance. J Bacteriol 1966; 92: 1364-1371.

7. Fenoll A, Berrón S, Vázquez JA. Analysis of penicillinaseproducing Neisseria gonorrhoeae isolates in Madrid (Spain) from 1983-85. Epidemiol Infect 1987; 99: 455-462.

8. Bygdeman S. Polyclonal and monoclonal antibodies applied to the epidemiology of gonococcal infection. In: Young $\mathrm{H}$,
McMillan A (eds) Immunological diagnosis of sexually transmitted diseases. New York, Marcel Dekker Inc. 1987: 117-165.

9. White LA, Kellogg DS. Neisseria gonorrhoeae identification in direct smears by a fluorescent antibody-counterstain method. Appl Microbiol 1965; 13: 171-174.

10. Selander RK, Caugant DA, Ochman H, Musser JM, Gilmour MN, Whittam TS. Methods of multilocus enzyme electrophoresis for bacterial population genetics and systematics. Appl Environ Microbiol 1986; 51 : 873-884.

11. Nei M. Estimation of average heterozygosity and genetic distance from a small sample of individuals. Genetics 1978; 89: $583-590$.

12. Hook EW, Holmes KK. Gonococcal infections. Ann Intern Med 1985; 102: 229-243.

13. Reyn A, Korner B, Bentzon MW. Effects of penicillin, streptomycin, and tetracycline on Neisseria gonorrhoeae isolated in 1944 and in 1957. Br J Vener Dis 1958; 34: 227-239.

14. Mendelman PM, Caugant DA, Kalaitzoglou G et al. Genetic diversity of penicillin G-resistant Neisseria meningitidis from Spain. Infect Immun 1989; 57: 1025-1029.

15. Porras $\mathrm{O}$, Caugant DA, Gray B, Lagergård T, Levin BR, Svanborg-Edén $C$. Difference in structure between type b and nontypable Haemophilus influenzae populations. Infect Immun 1986; 53: 79-89.

16. Ochman H, Whittman TS, Caugant DA, Selander RK. Enzyme polymorphism and genetic population structure in Escherichia coli and Shigella. J Gen Microbiol 1983; 129 . 2715-2726. 